\title{
Konfigurasi baterai lead acid pada sistem pengaturan motor BLDC untuk aplikasi mobil listrik
}

\author{
Adelia Octora Pristisahida ${ }^{1^{*}}$, Iyas Munawar ${ }^{2}$ \\ ${ }^{1}$ Program Studi Teknik Elektro, Universitas Nahdlatul Ulama Yogyakarta \\ Jl. Lowanu No.47, Sorosutan, Kec. Umbulharjo, Daerah Istimewa Yogyakarta 55162, Indonesia \\ ${ }^{2}$ Sekolah Teknik Elektro dan Informatika, Institut Teknologi Bandung \\ Jl. Ganesa No. 10, Kota Bandung, Jawa Barat 40132, Indonesia

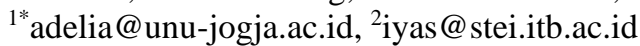

\begin{abstract}
ABSTRAK
Kendaraan listrik merupakan salah satu solusi teknologi yang saat ini dikembangkan untuk mengatasi permasalahan lingkungan akibat polusi udara. Jenis kendaraan ini menggunakan baterai sebagai sumber daya penggeraknya. Umumnya kendaraan listrik menggunakan baterai tunggal yang memiliki daya yang besar, seperti sepeda listrik. Namun, untuk mobil listrik sebuah baterai saja tidak mencukupi sebab dibutuhkan daya yang lebih besar dan siklus hidup yang lebih panjang. Oleh karena itu, perlu digunakan beberapa baterai sekaligus yang disusun dengan konfigurasi tertentu. Penelitian ini bertujuan melakukan studi terhadap konfigurasi baterai lead acid pada sistem pengaturan motor brushless direct current (BLDC) yang digunakan sebagai penggerak mobil listrik. Studi dilakukan secara eksperimen perangkat keras dengan membandingkan konfigurasi baterai secara paralel dan seri. Kemudian setiap konfigurasi diuji untuk beberapa jenis skenario perjalanan kendaraan untuk melihat performansinya. Hasil pengujian secara eksperimen menunjukkan bahwa baterai dengan konfigurasi paralel lebih efektif digunakan untuk skenario perjalanan dalam kota yang memiliki karakteristik stop and go, dengan daya maksimal yang dapat dikeluarkan oleh baterai adalah 7,68 W, sedangkan baterai dengan konfigurasi seri dapat digunakan untuk perjalanan yang lebih jauh dengan kondisi lintasan lurus dan datar, dengan daya maksimal $4,32 \mathrm{~W}$.
\end{abstract}

Kata kunci: baterai, lead acid, mobil listrik, motor BLDC

\begin{abstract}
Electric vehicles are one of the technological solutions that are currently being developed to overcome environmental problems due to air pollution. This type of vehicle uses a battery as a source of propulsion. Generally, electric vehicles use a single battery that has a large amount of power, such as electric bicycles. However, for electric cars, one battery is not sufficient because it requires more power and long cycle life. Therefore, it is necessary to use several batteries at once which are arranged in a certain configuration. This study aims to study the configuration of the lead acid battery in the brushless DC motor control system (BLDC) which is used as an electric car propulsion. The study was carried out in hardware experiments by comparing the battery configurations in parallel and series. Then each configuration is tested for several types of vehicle travel scenarios to see their performance. Experimental test results show that batteries with parallel configurations are more effective for travel scenarios in cities that have stop and go characteristics, while batteries with series configurations can be used for longer trips with straight and flat track conditions.
\end{abstract}

Keywords: battery, lead acid, electric vehicle, BLDC motor

\section{PENDAHULUAN}

Mobil merupakan salah satu jenis kendaraan yang populer di negara berkembang seperti di Indonesia. Umumnya, mobil yang banyak ditemukan adalah mobil konvensional dengan bahan bakar minyak sebagai sumber energi utama, sehingga menghasilkan emisi yang menyebabkan polusi udara. Bahan bakar minyak tersebut saat ini sudah mulai mengalami krisis dan kenaikan harga jual sebab kebutuhan yang meningkat. Sebagai solusi dari masalah tersebut maka dikembangkan mobil jenis hybrid dan mobil listrik. Mobil jenis hybrid adalah kendaraan yang memiliki dua sumber energi, yaitu bahan bakar minyak (primer) dan listrik (sekunder), sedangkan mobil listrik adalah kendaraan yang 
hanya berenergikan listrik. Kendaraan jenis ini mengeluarkan emisi yang sangat sedikit, sehingga tidak menyebabkan polusi udara.

Mobil listrik pada umumnya menggunakan baterai sebagai penggerak utamanya atau dikenal dengan istilah Battery Electric Vehicle (BEV). Berbagai jenis baterai telah diteliti untuk aplikasi mobil listrik seperti baterai lead acid, nickle metal hydride (Ni-MH), lithium-Ionium (Li-Ion), dan sodium nickle chloride $(\mathrm{Na} / \mathrm{NiCl} 2)$ [1]. Dari berbagai jenis baterai, jenis high-energy lithium metal merupakan baterai yang sampai saat ini dianggap paling baik untuk aplikasi mobil listrik karena memiliki daya dan energi yang paling besar [2]. Studi terkait baterai kendaraan listrik telah banyak dilakukan baik dari segi konfigurasi, sistem kontrol, maupun penghematan daya. Penelitian [3]-[5] memodelkan jenis baterai lead acid dan mensimulasikan penggunaannya pada mobil listrik untuk berbagai skenario perjalanan. Dari sisi sistem kontrol, berbagai metode juga telah diterapkan untuk mengoptimalkan kinerja baterai seperti ON/OFF [6], fuzzy logic [7], hingga kendali optimal [8]. Beberapa penelitian saat ini juga telah mengarah ke pemanfaatan sumber energi listrik lainnya seperti superkapasitor dan fuel cell sebagai energi tambahan jika diperlukan arus beban yang besar untuk menghemat penggunaan baterai [9]-[12]. Pada prinsipnya, penelitian terkait baterai pada kendaraan listrik adalah untuk memperpanjang jarak tempuh kendaraan listrik. Penggunaan baterai dengan konfigurasi dan sistem kontrol yang baik merupakan salah satu hal yang perlu dilakukan agar dapat dicapai penggunaan baterai yang optimal. Oleh karena itu, diperlukan studi konfigurasi mendasar yang dapat dijadikan standar acuan dalam mengembangkan teknologi baterai pada kendaraan listrik.

Penelitian ini bertujuan untuk melihat pengaruh konfigurasi seri dan konfigurasi paralel terhadap kecepatan, arus, dan daya baterai pada motor brushless direct current (BLDC). Motor BLDC merupakan salah satu jenis motor listrik yang dapat digunakan untuk kendaraan listrik karena efisiensinya [13]. Pada penelitian ini, kecepatan motor BLDC akan diubah menggunakan teknik pulse width modulation (PWM) dengan kenaikan duty cycle 10\%. Hal ini bertujuan untuk melihat pengaruh konfigurasi seri dan paralel baterai pada pembebanan motor BLDC. Untuk mewujudkan eksperimen tersebut, pada penelitian ini dibangun perangkat keras dan perangkat lunak yang dapat mendukung eksperimen. Motor yang digunakan adalah motor BLDC tiga fasa yang dilengkapi dengan driver khusus. Pengendalian kecepatan menggunakan teknik PWM yang dibangun pada mikrokontroler Arduino Uno. Kemudian pada pengujian dilakukan analisis pengaruh setiap konfigurasi pada kecepatan, arus, dan daya.

\section{METODE PENELITIAN}

Pada bagian ini akan dibahas mengenai model baterai lead acid, konfigurasi baterai seri, konfigurasi baterai paralel, perancangan perangkat keras, dan perancangan perangkat lunak.

\subsection{Model Baterai Lead Acid}

Baterai dapat dideskripsikan sebagai alat yang memiliki tegangan gaya gerak listrik (GGL-EMFelectromotive force) dimana tegangan GGL ini akan berbeda dengan tegangan terminal baterai. Tegangan GGL adalah tegangan yang didapatkan ketika baterai tidak ada beban atau rangkaian terbuka (open circuit), sedangkan tegangan terminal baterai adalah tegangan ketika rangkaian tertutup atau baterai diberi beban. Hal ini dijelaskan dengan rangkaian seperti pada Gambar 1.

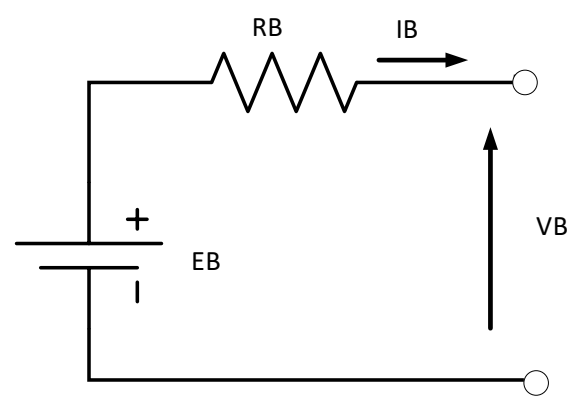

Gambar 1. Rangkaian eqivalen baterai lead acid 
Gambar 1 memperlihatkan bahwa terdapat hambatan $R_{s}$ pada baterai. Hambatan $R_{b}$ adalah polarisasi listrik ohmik yang disebabkan karena adanya resistansi pada material aktif baterai, yaitu kedua elektroda dan elektrolit pemisah elektroda. Model baterai pada gambar di atas memiliki Persamaan keluaran sebagai berikut.

$$
V_{b}=E_{b}-I_{b} R_{b}
$$

dimana

$V_{b} \quad=$ Tegangan terminal baterai

$I_{b} \quad=$ Arus baterai

$E_{b} \quad=$ EMF baterai

$R_{b} \quad=$ Hambatan dalam baterai

Dari Persamaan (1) terlihat bahwa tegangan pada terminal baterai $V_{b}$ selalu lebih kecil dari tegangan $E_{b}$ baterai selama pengosongan (discharge) dan akan naik selama pengisian (charge).

Besar EMF baterai satu dengan yang lain tidak akan pernah sama, walaupun berasal dari pabrik, dimensi, dan label yang sama. Begitu pula besar $R_{b}$ tiap baterai tidak akan sama. Dalam penggunaan baterai, besar EMF, $R_{b}$, dan arus yang keluar dari baterai harus selalu diperhatikan, terutama ketika baterai digunakan dengan konfigurasi seri atau paralel dan dengan kondisi pembebanan yang berbedabeda.

\subsection{Konfigurasi Baterai Paralel}

Baterai yang dikonfigurasikan secara paralel harus memiliki resistansi internal yang perbedaannya tidak lebih dari $20 \%$ dengan memiliki kapasitas dan tegangan yang sama. Gambar 2 menunjukkan konfigurasi baterai paralel.

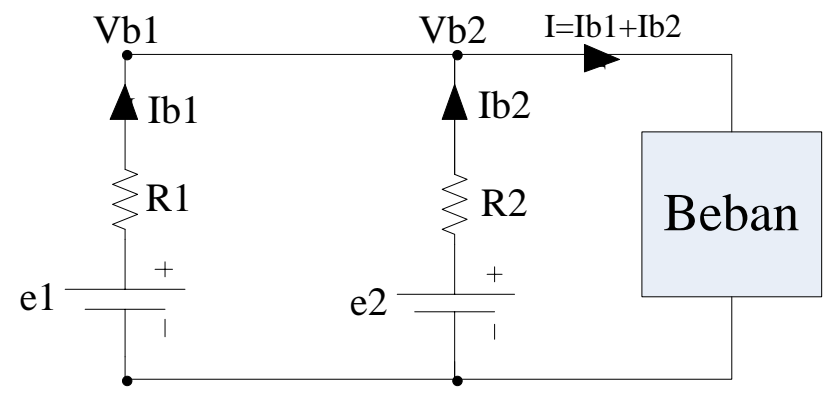

Gambar 2. Rangkaian baterai paralel

Tegangan EMF dan resistansi antar satu baterai dengan baterai lain tidak akan pernah sama persis, sehingga arus yang keluar dari baterai satu dan kedua besarnya akan berbeda. Bila rangkaian baterai paralel dibiarkan untuk waktu yang lama, pada waktu tertentu arus yang keluar dari baterai akan bernilai negatif atau berbalik arah masuk ke baterai. Satu baterai melakukan pengosongan dan baterai satunya akan melakukan pengisian. Hal ini yang menyebabkan baterai sebaiknya tidak dikonfigurasikan secara paralel tanpa adanya monitoring atau kendali pada arus keluarannya.

Dengan menggunakan Persamaan tegangan simpul, maka didapatkan Persamaan untuk rangkaian baterai paralel seperti pada Gambar 2 sebagai berikut:

$$
V_{b 1}=V_{b 2}=\left(I_{b 1}+I_{b 2}\right) \times R b
$$

dimana:

Vb1 = Tegangan terminal baterai 1

$\mathrm{Ib} 1=$ Arus baterai 1

$\mathrm{Vb} 2=$ Tegangan terminal baterai 2

$\mathrm{Ib} 2=$ Arus baterai 2

$$
e_{b 1}-I_{b 1} R_{1}=e_{b 2}-I_{b 2} R_{2}=\left(I_{b 1}+I_{b 2}\right) \times R b
$$


dimana:

eb1 = EMF baterai 1

eb2 = EMF baterai 2

$\mathrm{R} 1=$ Hambatan dalam Baterai 1

R2 = Hambatan dalam Baterai 2

Nilai $I_{2}$ dapat diketahui dengan menggunakan Persamaan berikut.

$$
\begin{gathered}
e_{b 1}-I_{b 1} R_{1}=I_{b 1} R b+I_{2} R b \\
I_{b 2}=\frac{e_{b 1}-I_{b 1} R_{1}-I_{b 1} R b}{R b}
\end{gathered}
$$

Dengan menggunakan proses subtitusi maka nilai $I_{b 1}$ dapat diketahui

$$
\begin{gathered}
e_{b 1}-I_{b 1} R_{1}=e_{b 2}-\left(\frac{e_{b 1}-I_{b 1} R_{1}-I_{b 1} R b}{R b}\right) R_{2} \\
e_{b 1} R b-I_{b 1} R_{1} R b=e_{b 2} R b-e_{b 1} R_{2}+I_{b 1} R_{1} R_{2}+I_{b 1} R_{2} R b \\
I_{b 1} R_{1} R b+I_{b 1} R_{1} R_{2}+I_{b 1} R_{2} R b=e_{b 1} R b+e_{b 1} R_{2}-e_{b 2} R b \\
I_{b 1}\left(R_{1} R_{2}+R_{2} R b+R_{1} R b\right)=e_{b 1} R b+e_{b 1} R_{2}-e_{b 2} R b \\
I_{b 1}=\frac{e_{b 1} R b+e_{b 1} R_{2}-e_{b 2} R b}{R_{1} R_{2}+R_{2} R b+R_{1} R b}
\end{gathered}
$$

Agar $I_{1}$ selalu bernilai positif atau tidak terjadi arus masuk ke baterai, maka mengikuti Persamaan berikut.

$$
\begin{gathered}
e_{b 1} R b+e_{b 1} R_{2}-e_{b 2} R b>0 \\
e_{b 1}>\frac{R b}{R b+R_{2}} e_{b 2}
\end{gathered}
$$

Melihat Persamaan (11) dan Persamaan (12) maka selama besar EMF baterai $1 \approx$ EMF baterai 2 , maka baterai dapat dikonfigurasikan secara paralel.

\subsection{Konfigurasi Baterai Seri}

Pada perancangan dengan konfigurasi baterai seri, dua buah baterai dengan beban disusun secara seri berurutan dan menjadi sebuah rangkaian tertutup seperti yang diperlihatkan pada Gambar 3 .

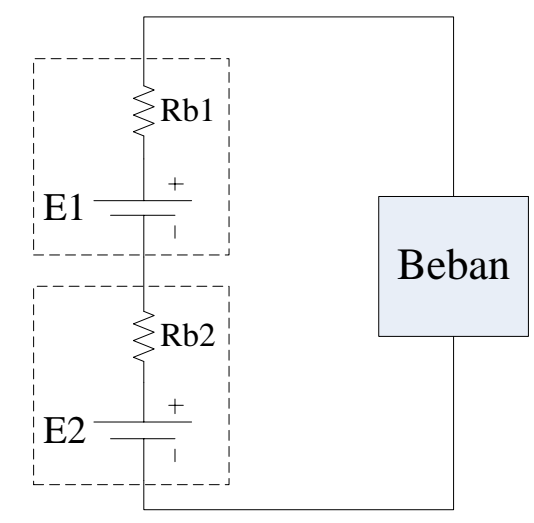

Gambar 3. Konfigurasi baterai seri 
Bila baterai dihubungkan seri seperti Gambar 3, maka arus mengalir akan sama pada setiap titik di rangkaian tersebut, berapa pun besar arusnya. Baterai disusun secara seri untuk mendapatkan tegangan yang lebih besar dari pada baterai tunggal. Namun, ketika baterai dikonfigurasikan secara seri kapasitas baterai harus sama, sehingga salah satu baterai tidak mengalami pengosongan terlebih dahulu. Model matematik besar arus untuk konfigurasi baterai seri dapat dibangun menggunakan hukum Kirchoff sebagai berikut.

$$
\begin{gathered}
V_{b 1}+V_{b 2}=I \times R b \\
e_{b 1}-I R_{1}+e_{b 2}-I R_{2}=I \times R b \\
I=\frac{e_{b 1}+e_{b 2}}{R b-R_{1}-R_{2}}
\end{gathered}
$$

\subsection{Perancangan Perangkat Keras}

Secara umum, diagram blok rancangan sistem perangkat keras pada penelitian ini ditunjukkan pada Gambar 4 dengan hasil implementasi ditampilkan pada Gambar 5.

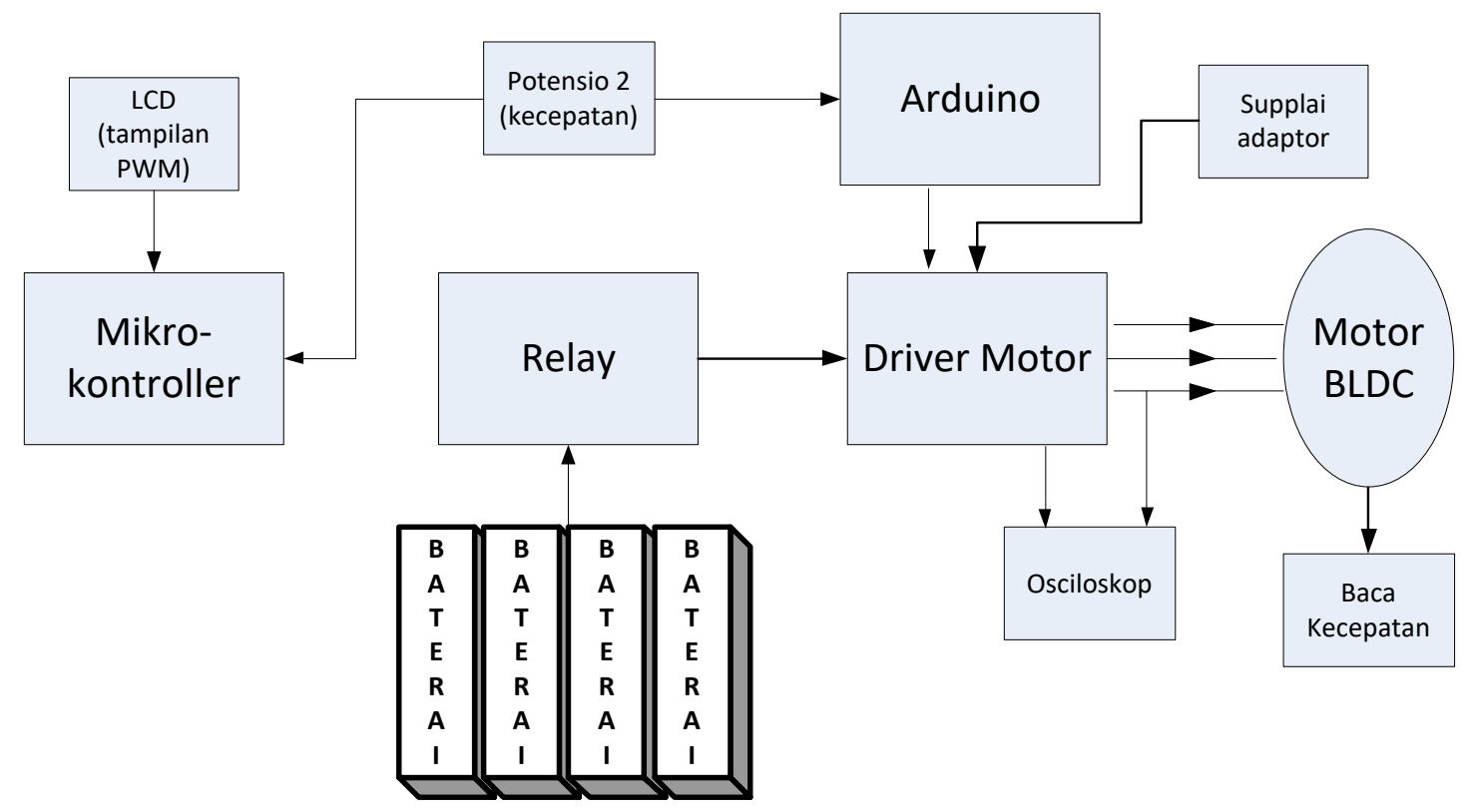

Gambar 4. Blok rancangan sistem
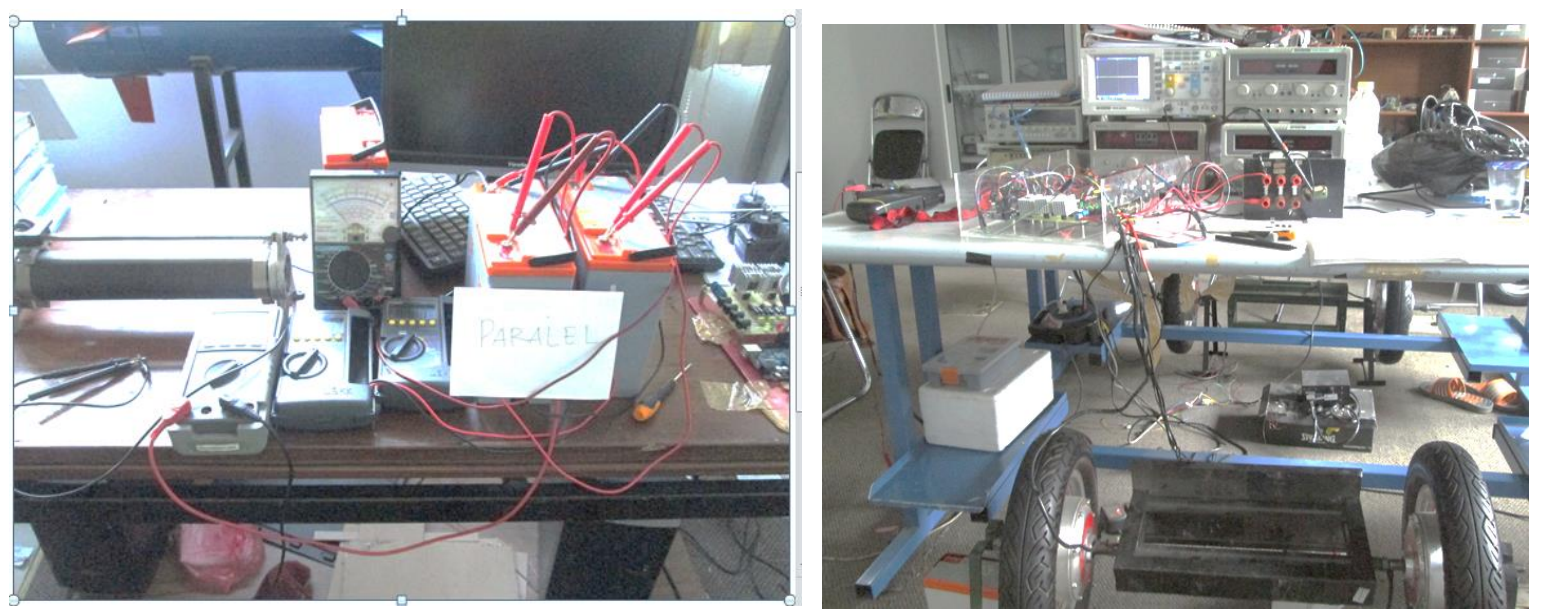

Gambar 5. Implementasi rancangan sistem 
Setiap bagian dari blok diagram akan dijelaskan sebagai berikut:

1. Mikrokontroler berfungsi untuk memberikan keluaran untuk mengatur kondisi relai dan untuk memberikan tampilan pada LCD. Mikrokontroler yang digunakan dalam penelitian ini adalah ATMega16.

2. Display akan menampilkan nilai PWM yang digunakan dan besar kecepatan motor BLDC serta konfigurasi baterai yang digunakan. Tampilan display menggunakan LCD 2x16 LMB162AFC.

3. Relai berfungsi untuk mengubah konfigurasi antar baterai sehingga dapat mengeluarkan tegangan 12 Volt, 24 Volt, dan 48 Volt.

4. Bank baterai terdiri dari empat buah baterai lead acid dengan spesifikasi 12 Volt $26 \mathrm{Ah}$. Baterai lead acid yang digunakan adalah merk Huawei OTODO dengan seri 6-DZM-22. Baterai ini dalam penggunaannya maksimal yang diperbolehkan adalah 50\%. Tegangan minimal yang diperbolehkan pada saat pemakaian adalah 12,75 Volt. Setelah mencapai tegangan tersebut baterai harus diisi ulang.

5. Arduino berfungsi untuk memberikan sinyal komutasi untuk driver sehingga dapat mengaktifkan motor BLDC dan memberikan sinyal PWM untuk mengatur kecepatan motor.

6. Potensio 2 berfungsi untuk mengatur kecepatan yang diimplementasikan pada motor BLDC.

7. Driver adalah driver motor BLDC yang digunakan. Driver ini antara lain berisi rangkaian inverter dan pengaman untuk Arduino menggunakan optocoupler.

8. Suplai adaptor digunakan untuk mencatu pengaman optocoupler yang digunakan.

\subsection{Perancangan Perangkat Lunak}

Arduino digunakan sebagai pengendali pada penelitian ini. Pengendali yang dimaksud adalah pengendali masuk inverter pada driver yang berfungsi untuk memicu stator motor BLDC sehingga rotor dapat berputar. Seperti yang telah ditampilkan pada Tabel 1 untuk kombinasi pensaklaran inverter, kemudian diwujudkan dalam bentuk program. Gambar 6 berikut adalah flowchart yang digunakan.

Tabel 1. Tabel kombinasi pensaklaran inverter

\begin{tabular}{|c|c|c|c|c|c|c|c|c|c|c|c|c|}
\hline \multirow{2}{*}{ Step } & \multicolumn{3}{|c|}{ Hall Sensor } & \multicolumn{3}{|c|}{ Fasa Terminal } & \multicolumn{6}{|c|}{ Switch MOSFET } \\
\hline & $\mathbf{K}$ & $\mathbf{B}$ & $\mathbf{H}$ & $\mathbf{U}$ & $\mathbf{V}$ & $\mathbf{W}$ & KL & KH & BL & BH & HL & HH \\
\hline 1 & 1 & 1 & 0 & + & $\mathrm{NC}$ & - & 0 & 0 & 0 & 1 & 1 & 0 \\
\hline 2 & 0 & 1 & 0 & - & + & $\mathrm{NC}$ & 1 & 0 & 0 & 1 & 0 & 0 \\
\hline 3 & 0 & 1 & 1 & $\mathrm{NC}$ & + & + & 1 & 0 & 0 & 0 & 0 & 1 \\
\hline 4 & 0 & 0 & 1 & - & $\mathrm{NC}$ & + & 0 & 0 & 1 & 0 & 0 & 1 \\
\hline 5 & 1 & 0 & 1 & + & - & $\mathrm{NC}$ & 0 & 1 & 1 & 0 & 0 & 0 \\
\hline 6 & 1 & 0 & 0 & $\mathrm{NC}$ & - & - & 0 & 1 & 0 & 0 & 1 & 0 \\
\hline
\end{tabular}

Pada Gambar 6 terdapat dua flowchart. Untuk gambar sebelah kiri adalah flowchart program komutasi inverter tiga fasa, sehingga driver dapat memberikan masukan pada stator dan rotor dapat berputar. Gambar di sebelah kanan adalah flowchart untuk pembangkit sinyal PWM yang nanti digunakan untuk mengatur kecepatan motor BLDC. 


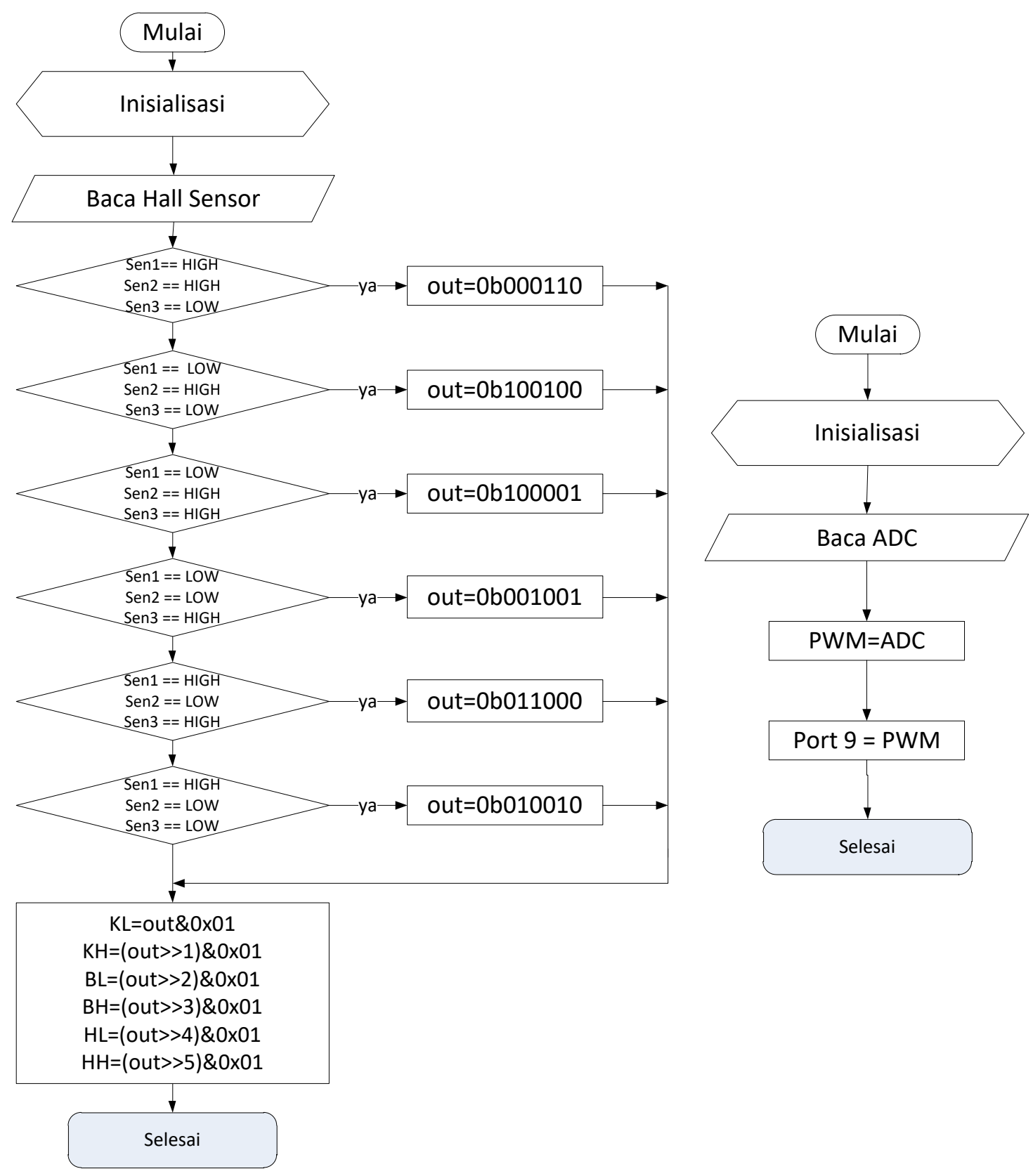

Gambar 6. Flowchart komutasi inverter-driver

\section{HASIL DAN PEMBAHASAN}

\subsection{Pengujian Konfigurasi Paralel}

Pengujian akan dilakukan dua kali, pertama menggunakan beban resistif dan kedua menggunakan motor BLDC sebagai beban. Baterai yang digunakan dua buah masing-masing memiliki resistansi internal 0,273 $\mathrm{Ohm}$ dan 0,309 $\mathrm{Ohm}$. Bila melihat persyaratan konfigurasi baterai paralel menggunakan Persamaan (15) dengan $\mathrm{Rb}=4 \mathrm{Ohm}$, diperoleh hasil yang memenuhi syarat yaitu $V_{b 1}(13,22)>$ $V_{b 2}(11,6)$.

Pada pengujian pertama, baterai yang digunakan untuk pengujian ini salah satu diisi penuh hingga tegangan 13,2 Volt. Sedangkan baterai satunya dibiarkan kosong dengan tegangan 12,6 Volt. Hal ini dilakukan untuk melihat respon penurunan tegangan baterai ketika dikonfigurasikan secara paralel. Konfigurasi baterai paralel diujikan dengan diberi beban 4,5 $\mathrm{Ohm}$ dan dikosongkan hingga tegangan 11,75 Volt. Hasil pengukuran ditunjukkan pada Gambar 9. 


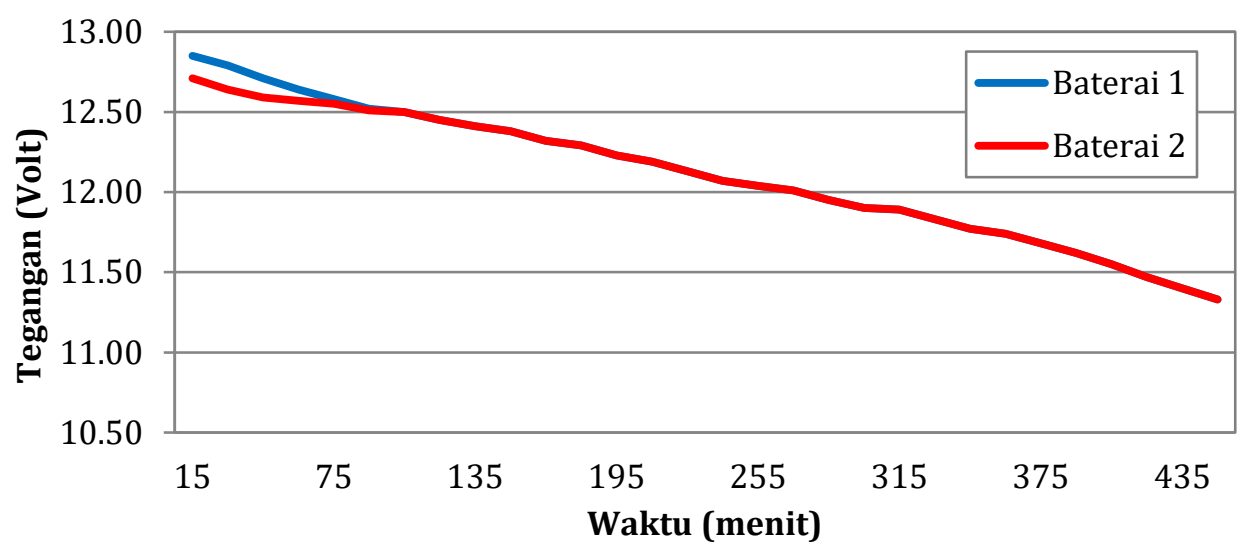

Gambar 9. Karakteristik tegangan konfigurasi baterai paralel

Pada Gambar 9 terlihat bahwa pada konfigurasi paralel penurunan tegangan yang dialami oleh baterai 1 dan baterai 2 seimbang, walaupun tegangan awal baterai tidak sama. Hal ini menunjukkan bahwa arus yang dikeluarkan baterai pada awal pengosongan tidak sama. Baterai 1 dengan tegangan awal tinggi mengeluarkan arus yang lebih besar dibanding baterai 2. Dari Gambar 9 terlihat pada menit ke-125 tegangan kedua baterai telah sama dan penurunan tegangannya juga sama untuk waktu berikutnya. Hal ini menunjukkan bahwa terdapat arus sirkulasi antar baterai. Selain baterai 1 melakukan pengosongan terhadap beban, ada arus dari baterai 1 yang mengalir ke baterai 2, sehingga baterai 2 melakukan pengisian (charging). Menurut penelitian [6], adanya selisih 20\% dari besar resistansi internal baterai yang diparalel akan menyebabkan umur baterai semakin pendek sebanyak 40\%. Terutama jika baterai digunakan pada pembebanan yang tinggi seperti pada mobil listrik. Adanya selisih besar resistansi internal akan menyebabkan distribusi arus yang dikeluarkan tiap baterai tidak sama. Sehingga pada suatu saat terdapat arus pengosongan besar pada baterai yang tidak diharapkan juga dapat mengurangi masa hidup baterai. Hal ini akan terjadi jika baterai dikonfigurasikan secara paralel. Namun hal ini dapat diatasi dengan membangun sebuah manajemen sistem baterai yang dapat memonitor dan mengontrol kondisi dan kegiatan baterai.

\subsection{Pengujian Konfigurasi Seri}

Sebelum pengujian ini dilakukan, baterai 1 dan baterai 2 diisi hingga penuh. Tegangan baterai 1 dan baterai 2 masing-masing ketika penuh adalah 13,3 Volt dan 13,1 Volt. Adanya selisih tegangan kedua baterai ketika penuh disebabkan karena masa penggunaan baterai tidak sama, sehingga resistansi internal baterai tidak sama. Pada pengujian pertama, konfigurasi baterai seri akan diujikan menggunakan beban 8,5 Ohm dan dikosongkan hingga tegangan 11,75 Volt. Hasil pengujian ini ditunjukkan pada Gambar 10.

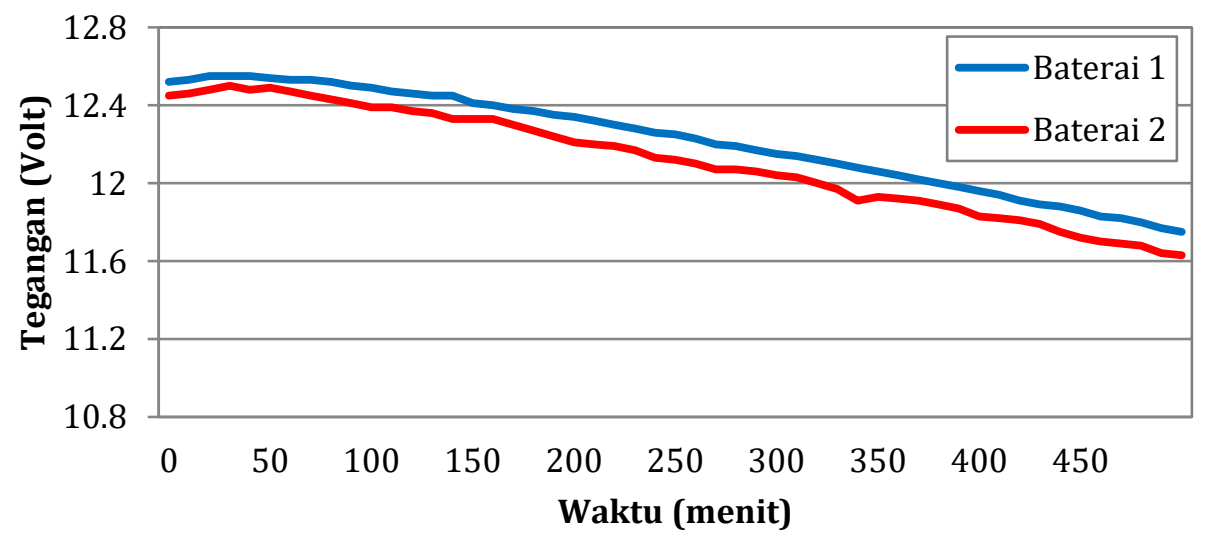

Gambar 10. Karakteristik tegangan konfigurasi baterai seri 
Pada Gambar 10 terlihat bahwa pada konfigurasi seri penurunan tegangan yang dialami oleh baterai 1 dan baterai 2 seimbang, walaupun tegangannya tidak pernah sama. Sebab pada awal pengukuran tegangan open circuit kedua baterai tidak sama. Jika dibandingkan dengan konfigurasi paralel yang tegangan kedua baterai menjadi sama, pada konfgurasi seri ini tegangan baterai tetap pada garisnya. Hal ini menunjukkan arus yang dikeluarkan baterai seimbang satu sama lain dan tiap baterai tidak mengeluarkan arus besar yang tidak diharapkan seperti pada konfigurasi paralel.

\subsection{Pengujian Konfigurasi Baterai pada Motor BLDC}

Pengujian berikutnya dilakukan menggunakan beban satu buah motor BLDC dengan konfigurasi baterai paralel dan seri. Motor BLDC yang digunakan berbeban kecil berupa roda yang diasumsikan konstan. Pengujian dilakukan dengan mengubah duty cycle PWM mulai dari 0\% hingga 100\% sehingga kecepatan motor juga akan berubah. Dari pengujian ini, kemudian diamati respon kecepatan motor, arus baterai, dan daya baterai. Adapun hasil pengujian dapat dilihat pada Gambar 11, Gambar 12, dan Gambar 13.

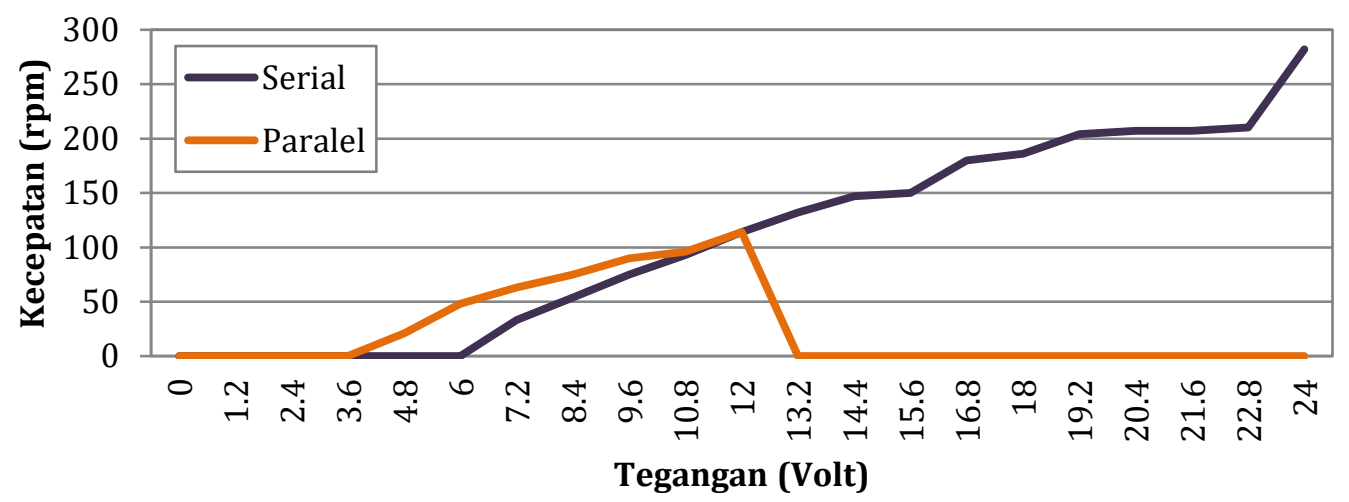

Gambar 11. Pengaruh konfigurasi seri dan paralel terhadap kecepatan motor BLDC

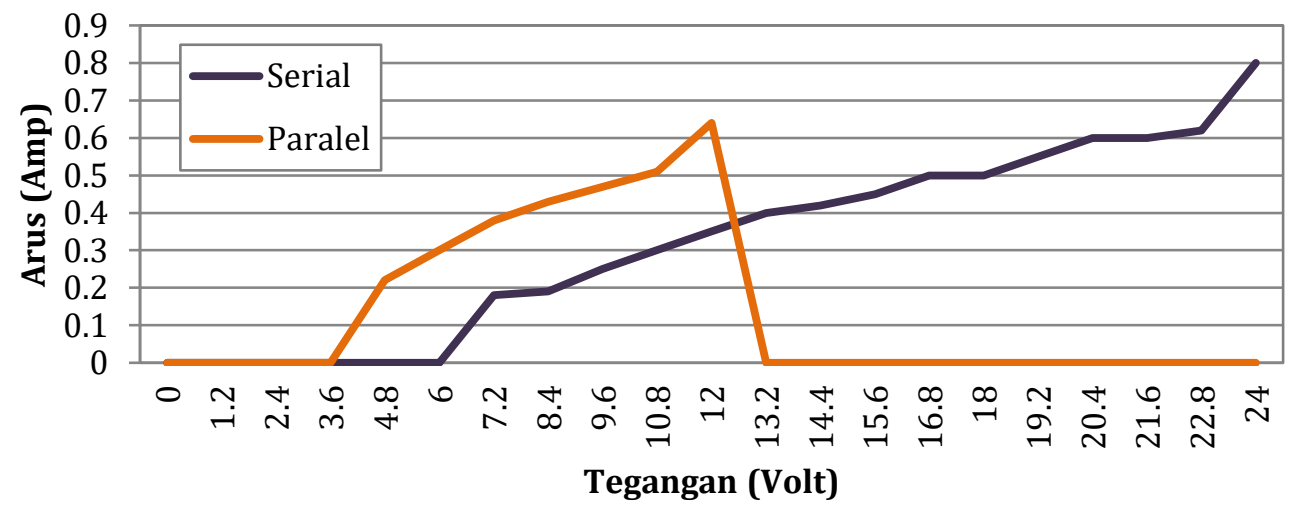

Gambar 12. Pengaruh konfigurasi seri dan paralel terhadap arus baterai

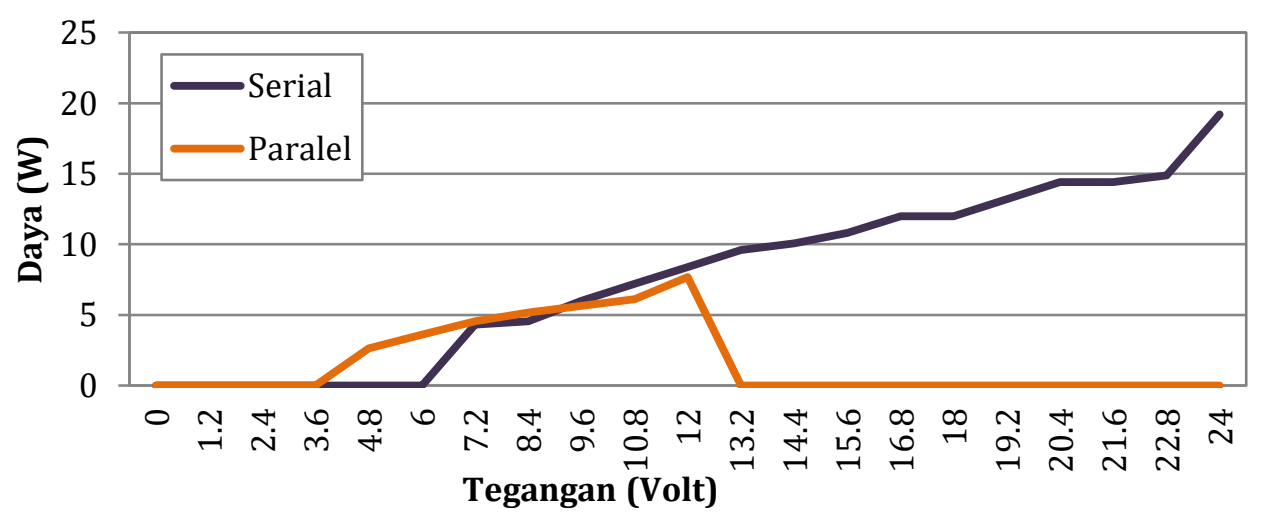

Gambar 13. Pengaruh konfigurasi baterai seri paralel terhadap daya baterai 
Gambar 11 menunjukkan respon kecepatan motor BLDC untuk konfigurasi baterai paralel dan seri. Dari hasil pengujian terlihat bahwa konfigurasi baterai paralel dapat menggerakkan motor mulai pada duty cycle $40 \%$ atau pada tegangan sekitar 4,8 V dari tegangan maksimum $12 \mathrm{~V}$. Pada konfigurasi seri, motor dapat bergerak pertama kali dengan duty cycle $30 \%$ atau pada tegangan sekitar $7,2 \mathrm{~V}$ dari tegangan maksimal $24 \mathrm{~V}$. Pada pengujian tegangan baterai paralel di atas $12 \mathrm{~V}$, terlihat motor tidak dapat berputar, sedangkan pada konfigurasi seri motor masih berputar dan kecepatannya meningkat. Dari pengujian ini dapat disimpulkan bahwa konfigurasi paralel tidak dapat digunakan untuk motor BLDC pada kecepatan tinggi, namun baik digunakan untuk kecepatan rendah, sedangkan konfigurasi baterai seri dapat digunakan untuk kecepatan tinggi dan kecepatan rendah.

Gambar 12 menunjukkan respon arus baterai yang dihasilkan pada pengujian dengan motor BLDC. Hasil pengujian menunjukkan bahwa pada kecepatan yang sama, arus baterai yang dihasilkan oleh konfigurasi baterai paralel lebih besar dibanding konfigurasi baterai seri sekitar dua kali lipatnya. Hal ini disebabkan karena tegangan pada konfigurasi seri lebih besar di banding konfigurasi baterai paralel sehingga arus yang dihasilkan lebih kecil. Dengan demikian, konfigurasi baterai paralel lebih tepat digunakan saat arus yang dibutuhkan besar, seperti saat kondisi awal motor pertama kali mulai bergerak (starting point) atau ketika kondisi perjalanan stop and go.

Gambar 13 menunjukkan daya yang dihasilkan dari pengujian pada motor BLDC. Dari hasil pengujian diperoleh untuk konfigurasi paralel daya maksimal yang dapat keluarkan adalah 7,68 $\mathrm{W}$, sedangkan konfigurasi seri dapat menghasilkan daya maksimal 4,32 W. Jika dilihat, daya yang dihasilkan konfigurasi paralel lebih besar hampir dua kali lipat. Hal ini berbanding lurus dengan arus yang dihasilkan seperti pada pengujian respon arus. Jika diamati pada kondisi liniernya, pada kecepatan yang sama daya baterai yang dihasilkan oleh konfigurasi baterai seri dan paralel besarnya tidak berbeda jauh. Namun, dengan daya yang hampir sama besar ini, konfigurasi baterai serial menggunakan tegangan yang lebih besar sehingga arusnya lebih kecil, sedangkan konfigurasi paralel menggunakan tegangan yang lebih kecil, sehingga arusnya lebih besar.

\section{KESIMPULAN}

Konfigurasi baterai yang telah dirancang dan diintegrasikan dengan driver motor BLDC pada penelitian ini. Dua buah konfigurasi baterai lead acid diuji pada beberapa skenario untuk menggerakan motor BLDC. Hasil pengujian secara eksperimen menunjukkan bahwa baterai dengan konfigurasi paralel lebih efektif digunakan untuk skenario perjalanan dalam kota yang memiliki karakteristik stop and go, dengan daya maksimal yang dapat dikeluarkan oleh baterai adalah 7,68 W, sedangkan baterai dengan konfigurasi seri dapat digunakan untuk perjalanan yang lebih jauh dengan kondisi lintasan lurus dan datar, dengan daya maksimal 4,32 W.

Selain itu, hasil pengujian menunjukkan bahwa dengan konfigurasi baterai paralel, saat terjadi pembebanan arus masing-masing baterai tidak sama dan terdapat arus sirkulasi. Konfigurasi ini tidak dapat digunakan pada kecepatan tinggi karena tegangan maksimalnya hanya $12 \mathrm{~V}$. Konfigurasi paralel untuk implementasi lebih lanjut sebaiknya tidak digunakan tanpa menggunakan BMS. Dengan konfigurasi baterai seri, saat terjadi pembebanan arus masing-masing baterai sama dan penurunan tegangan tiap baterai seragam. Konfigurasi seri dapat digunakan pada kondisi kecepatan tinggi dan kecepatan rendah. Untuk penelitian selanjutnya, hal yang disarankan adalah konfigurasi baterai paralel dapat dipilih tetapi harus menggunakan sistem manajemen baterai untuk menjamin pembagian arus baterai sama dan tidak ada arus sirkulasi antar baterai.

\section{UCAPAN TERIMA KASIH}

Ucapan terima kasih diberikan kepada Laboratorium Sistem Kendali dan Komputer (LSKK), STEI ITB yang telah mendukung fasilitas peralatan laboratorium dalam pelaksanaan penelitian ini.

\section{REFERENSI}

[1] A. M. Andwari, A. Pesiridis, S. Rajoo, R. Martinez-Botas, and V. Esfahanian, "A review of Battery Electric Vehicle technology and readiness levels," Renewable and Sustainable Energy Reviews, vol. 78, pp. 414-430, 2017.

[2] S. Chen, F. Dai, and M. Cai, "Opportunities and challenges of high-energy lithium metal batteries for electric vehicle applications," ACS Energy Letters, vol. 5, no. 10, pp. 3140-3151, 2020. 
[3] B. V. Rajanna and M. K. Kumar, "Dynamic model development for lead acid storage battery," Indonesian Journal of Electrical Engineering and Computer Science (IJEECS), vol. 15, no. 2, pp. 609-619, 2019.

[4] L. Kasprzyk, "Modelling and analysis of dynamic states of the lead-acid batteries in electric vehicles," Eksploatacja i Niezawodność, vol. 19, no. 2, 2017.

[5] D. Burzyński and L. Kasprzyk, "Modelling and simulation of lead-acid battery pack powering electric vehicle," in E3S Web of Conferences, vol. 14, 2017, p. 01041.

[6] R. Carter, A. Cruden, and P. J. Hall, "Optimizing for efficiency or battery life in a battery/supercapacitor electric vehicle," IEEE Transactions on Vehicular Technology, vol. 61, no. 4, pp. 1526-1533, 2012.

[7] Y. Ma, P. Duan, Y. Sun, and H. Chen, "Equalization of lithium-ion battery pack based on fuzzy logic control in electric vehicle," IEEE Transactions on Industrial Electronics, vol. 65, no. 8, pp. 6762-6771, 2018.

[8] J. Yang, W. Wang, K. Ma, and B. Yang, "Optimal dispatching strategy for shared battery station of electric vehicle by divisional battery control," IEEE Access, vol. 7, pp. 38224-38235, 2019.

[9] L. Kouchachvili, W. Yaïci, and E. Entchev, "Hybrid battery/supercapacitor energy storage system for the electric vehicles," Journal of Power Sources, vol. 374, pp. 237-248, 2018.

[10] Y. Wang, Z. Sun, and Z. Chen, "Energy management strategy for battery/supercapacitor/fuel cell hybrid source vehicles based on finite state machine," Applied energy, vol. 254, pp. 113707, 2019.

[11] Z. Fu, Z. Li, P. Si, and F. Tao, "A hierarchical energy management strategy for fuel cell/battery/supercapacitor hybrid electric vehicles," International Journal of Hydrogen Energy, vol. 44, no. 39, pp. 22146-22159, 2019.

[12] Q. Zhang and G. Li, "Experimental study on a semi-active battery-supercapacitor hybrid energy storage system for electric vehicle application," IEEE Transactions on Power Electronics, vol. 35, no. 1, pp. 1014$1021,2019$.

[13] W. Khan-Ngern, W. Keyoonwong, N. Chatsiriwech, P. Sangnopparat, P. Mattayaboon, and P.Worawalai, "High performance BLDC motor control for electric vehicle," in 2018 International Conference on Engineering, Applied Sciences, and Technology (ICEAST), 2018, pp. 1-4. 
